Pesq. Vet. Bras. 35(7):605-612, julho 2015 DOI: $10.1590 /$ S0100-736X2015000700002

\title{
Supplementation of fetal bovine serum alters histone modification H3R26me2 during preimplantation development of in vitro produced bovine embryos ${ }^{1}$
}

\author{
Daniel R. Arnold ${ }^{2}$, Carolina A.P. Corrêa ${ }^{3}$, Laura L.G. Lorena ${ }^{4}$, Roberta C. Gaspar ${ }^{3}$, \\ Guilherme F. Rossi ${ }^{3}$, Aderson M. Ifran ${ }^{3}$, João C.T. Penteado ${ }^{4}$, Gisele Mingoti ${ }^{4}$ \\ and Flavia L. Lopes ${ }^{4 *}$
}

\begin{abstract}
Arnold D.R., Corrêa C.A.P., Lorena L.L.G., Gaspar R.C., Rossi G.F., Ifran A.M., Penteado J.C.T., Mingoti G. \& Lopes F.L. 2015. Supplementation of fetal bovine serum alters histone modification H3R26me2 during preimplantation development of in vitro produced bovine embryos. Pesquisa Veterinária Brasileira 35(7):605-612. Departamento de Apoio, Produção e Saúde Animal, Faculdade de Medicina Veterinária de Araçatuba, Universidade Estadual Paulista, Rua Clovis Pestana 793, Araçatuba, SP 16050-680, Brazil. E-mail: flavialopes@fmva.unesp.br

In vitro production (IVP) of bovine embryos is not only of great economic importance to the cattle industry, but is also an important model for studying embryo development. The aim of this study was to evaluate the histone modification, H3R26me2 during pre-implantation development of IVP bovine embryos cultured with or without serum supplementation and how these in vitro treatments compared to in vivo embryos at the morula stage. After in vitro maturation and fertilization, bovine embryos were cultured with either 0 or $2.5 \%$ fetal bovine serum (FBS). Development was evaluated and embryos were collected and fixed at different stages during development (2-, 4-, 8-, 16-cell, morula and blastocyst). Fixed embryos were then used for immunofluorescence utilizing an antibody for H3R26me2. Images of stained embryos were analyzed as a percentage of total DNA. Embryos cultured with 2.5\% FBS developed to blastocysts at a greater rate than 0\%FBS groups $(34.85 \pm 5.43 \%$ vs. $23.38 \pm 2.93 \%$; $\mathrm{P}<0.05)$. Levels of H3R $26 \mathrm{me} 2$ changed for both groups over development. In the $0 \%$ FBS group, the greatest amount of H3R26me 2 staining was at the 4-cell $(\mathrm{P}<0.05), 16$-cell $(\mathrm{P}<0.05)$ and morula $(\mathrm{P}<0.05)$ stages. In the $2.5 \%$ FBS group, only 4-cell stage embryos were significantly higher than all other stages $(\mathrm{P}<0.01)$. Morula stage in vivo embryos had similar levels as the $0 \% \mathrm{FBS}$ group, and both were significantly higher than the $2.5 \% \mathrm{FBS}$ group. These results suggest that the histone modification H3R26me2 is regulated during development of pre-implantation bovine embryos, and that culture conditions greatly alter this regulation.
\end{abstract}

INDEX TERMS: Bovine, embryo development, H3R26me2, in vitro produced, fetal bovine serum.

RESUMO.- [Suplementação com soro fetal bovino altera a modificação de histona H3R26me2 durante o período pré-implantacional em embriões bovinos produzidos

\footnotetext{
${ }^{1}$ Received on September 11, 2014.

Accepted for publication on July 23, 2015.

${ }^{2}$ In Vitro Brasil S/A, Rodovia SP-340 Km 166, Cx. Postal 238, Mogi Mirim, SP13800-970, Brazil.E-mails: dan.arnold113@gmail.com, carolinaalves@ usp.br

${ }^{3}$ Faculdade de Ciências Agrárias e Veterinárias, Universidade Estadual Paulista (Unesp), Via de Acesso Prof. Paulo Donato Castellane s/n, Jabo-
}

in vitro.] A produção in vitro (PIV) de embriões de bovinos não é apenas de grande importância econômica para a pecuária, mas é também um importante modelo para estudar

\footnotetext{
ticabal, SP 14884-900, Brazil. E-mails: roberta_cordeirogaspar@hotmail. com, guilhermemedvet@yahoo.com, amifran_@hotmail.com

${ }^{4}$ Departamento de Apoio, Produção e Saúde Animal, Faculdade de Medicina Veterinária de Araçatuba, Unesp, Rua Clovis Pestana 793, Araçatuba, SP 16050-680, Brazil. E-mails: lalu542@hotmail.com, jctpenteado@hotmail.com, gmingoti@fmva.unesp.br; *Corresponding author: flavialopes@ fmva.unesp.br
} 
o desenvolvimento embrionário. 0 objetivo deste estudo foi avaliar a modificação de histona, H3R26me2 durante o desenvolvimento pré-implantacional em embriões bovinos produzidos in vitro, cultivados com ou sem suplementação de soro fetal bovino (SFB), bem como comparar essa modificação específica entre mórulas produzidas in vitro e in vivo. Após a maturação in vitro e fertilização, embriões foram cultivados com suplementação de 0 ou $2,5 \%$ SFB. 0 desenvolvimento embrionário foi avaliado e embriões foram coletados e fixados em diferentes fases durante o desenvolvimento (2, 4, 8 e 16 células, mórula e blastocisto). Os embriões fixados foram avaliados por imunofluorescência utilizando um anticorpo para H3R26me2. Imagens de embriões corados foram analisadas baseadas na porcentagem do DNA total. Embriões cultivados com 2,5\% SFB tiveram uma taxa de desenvolvimento ao estágio de blastocisto maior que o grupo que não recebeu suplementação com SFB $(34.85 \pm 5,43 \%$ vs $23.38 \pm, 93 \%$; $P<0,05)$. Níveis de H3R26me2 variaram para ambos os grupos ao longo do desenvolvimento. No grupo $0 \% \mathrm{SFB}$, a marcação para H3R$26 \mathrm{me} 2$ foi mais intensa nos estágios de 4 células $(\mathrm{P}<0,05)$, 16 células $(\mathrm{P}<0,05)$ e mórula $(\mathrm{P}<0.05)$. No grupo $2.5 \% \mathrm{SFB}$, apenas os embriões de 4 células tiveram marcação significativamente maior que todas as outras fases $(\mathrm{P}<0,01)$. Mórulas produzidas in vivo apresentaram níveis de H3R$26 \mathrm{me} 2$ semelhantes ao grupo $0 \% \mathrm{SFB}$, e ambos foram significativamente maiores que o grupo 2.5\% SFB. Estes resultados sugerem que a modificação de histona H3R26me2 é regulada durante o desenvolvimento pré-implantacional de embriões bovinos, e que as condições de cultura alteram de maneira importante esta regulação.

TERMOS DE INDEXAÇÃO: Bovino, desenvolvimento embrionário, H3R26me2, produção in vitro, soro fetal bovino.

\section{INTRODUCTION}

In vitro production (IVP) of embryos has revolutionized the way infertility is addressed. Since the birth of Louise Brown in 1978 (Steptoe \& Edwards 1978), fertility clinics worldwide have adopted this procedure. Besides humans, another industry where IVP has become widely accepted is the cattle industry. In 2011, 453,471 bovine IVP embryos were produced, with 343,927 being used for embryo transfer (Stroud 2012). While production of in vitro embryos is common, the rate of development is still very low when compared to embryos produced in vivo (Hansen et al. 2010). These low results are primarily due to the inability to replicate the in vivo environment in a laboratory setting.

Conditions for which embryos are exposed prior to implantation are vital for proper embryonic development and successful establishment of pregnancy (Hansen et al. 2010; Besenfelder et al. 2012). This is most evident in IVP embryos, where changes to culture conditions can dramatically affect embryo developmental rates, and remains a major field of research.

The source of protein in media is an area of great interest. Fetal bovine serum (FBS) is the most common protein source in media. Culture media containing FBS generally produce better blastocyst rates, due to the growth factors and other known and unknown components that the growing embryo requires (Van Langendonckt et al. 1997), even though early embryo development may be delayed (Gardner 1998, Thompson 2000). In addition, the use of FBS in IVP systems appears to be more important for certain breeds of cattle. Leivas and co-authors (Leivas et al. 2011) reported improved blastocyst rates for IVP Bos indicus embryos cultured with $2 \%$ FBS than embryos cultured with BSA alone. No differences in blastocyst rates were identified for embryos produced from Bos taurus oocytes (Leivas et al. 2011). These results suggest another difference in sub-species. However, the drawbacks to using serum include variability in composition between batches, its undefined nature and the risk of contamination. In addition, the presence of serum during culture alters gene expression and tolerance to cryopreservation, when compared to in vivo embryos [for review see Lonergan et al. 2006). Similar results are found in mice (Khosla et al., 2001). These differences in gene expression may be due to effects on epigenetic regulation.

Epigenetic mechanisms appear to be the most sensitive factors affected by environmental changes like culture conditions (Niemann \& Wrenzycki 2000, Duranthon et al. 2008, Kohda et al. 2012). Histone modification is one such epigenetic mechanism that is critical to embryo development of several species such as mice (Corry et al. 2009), cattle (Santos et al. 2003, Enright et al. 2005, Wee et al. 2006, Maalouf et al. 2008, Ross et al. 2008), pig (Park et al. 2009, Gao et al. 2010), sheep (Hou et al. 2008) and human (Zhang et al. 2012). In mice, Sarmento et al. (2004), describes two types of histone patterns during preimplantation development, a consistent, stable mark during development and a dynamic, reversible mark. The highly dynamic marks are often associated with critical events, such as the transition to embryonic genome activation or the first cellular differentiation from totipotent cells into the inner cell mass and trophectoderm [for review see Mason et al. 2012). Two examples are trimethylation of lysines 9 and 27 of histone $\mathrm{H} 3$ which are enriched in the ICM compared with the trophectoderm (Erhardt et al. 2003). Epigenetic modifications are related to important stages of embryonic development.

Methylation of arginine residues in histone proteins are also critical during preimplantation. Like lysine methylation, arginine methylation has been associated with both transcriptional activation and inhibition (Di Lorenzo \& Bedford 2011). In murine embryos, arginine methylation has been linked with determining cell fate. Torres-Padilla et al. (2007) reported differences in H3R26me2 levels between blastomeres of 4-cell stage embryos. They also describe that the blastomere with the least amount of H3R26me2 would subsequently give rise to the trophoblast cells, whereas the remaining blastomeres will develop into the inner cell mass (Torres-Padilla et al. 2007). Regulation of this particular histone modification has not been documented in bovine embryos.

In cattle, where much research has focused on the altered reprogramming of histones in embryos produced by somatic cell nuclear transfer, (Santos et al. 2003, Morgan et al. 2005, Wee et al. 2006) fewer studies have examined 
the histone modifications throughout preimplantation stages (Maalouf et al. 2008, Ross et al. 2008) or the effects of culture conditions. Specific epigenetic patterns within each embryonic stage allow for proper development and successful pregnancy to ensue (Palini et al. 2011). Bovine embryos provide another important model for investigating the effects of IVP on epigenetic processes. Therefore, the current study examined the profile of H3R26me2 during bovine embryonic development in vitro in the presence or absence of fetal bovine serum and how H3R26me2 levels compared to in vivo embryos at the morula stage.

\section{MATERIALS AND METHODS}

\section{Production of in vitro and in vivo embryos}

In vitro fertilized (IVF) embryos were produced from oocytes obtained from slaughterhouse. Oocytes were matured in vitro as previously described (Bordignon et al. 2003). Briefly, cumulus-oocyte complexes (COC) were aspirated from 2 to $7 \mathrm{~mm}$ follicles and washed in Hepes-buffered TCM199 (Sigma-Aldrich Corporation, St Louis, Missouri, USA) supplemented with 10\% (v/v) FBS. Only COCs with several layers of cumulus cells and with homogenous oocyte cytoplasm were selected. Groups of 25 COCs were cultured in 100 $\mu$ l drops of IVM media [bicarbonate-buffered TCM199 (Gibco BRL, Grand Island, New York, USA) supplement with $10 \%$ FBS, $50 \mu \mathrm{g} / \mathrm{ml}$ of LH (Ayerst, London, ON, Canada), $1 \mu \mathrm{g} / \mathrm{ml}$ of FSH (Follitropin-V, Vetrepharm), $1 \mu \mathrm{g} / \mathrm{ml}$ of estradiol-17ß (Sigma-Aldrich), $22 \mu \mathrm{g} / \mathrm{ml}$ pyruvate (Sigma-Aldrich), and $83.4 \mu \mathrm{g} / \mathrm{ml}$ of amicacina (Sigma-Aldrich)]. Matured COCs were fertilized in vitro as previously described (Parrish et al. 1986) and cultured in $50 \mu \mathrm{l}$ drops of modified synthetic oviductal fluid (mSOF; $108 \mathrm{mM} \mathrm{NaCl}$, 7.2mM KCl, $0.5 \mathrm{mM} \mathrm{MgCl}_{2}, 2.5 \mathrm{mM} \mathrm{NaHCO}, 1.7 \mathrm{mM} \mathrm{CaCl} 2-\mathrm{H} 2 \mathrm{O}$, $0.5 \mathrm{mM}$ glucose $0.33 \mathrm{mM}$ pyruvic acid, $3 \mathrm{mM}$ lactic acid, $150 \mu \mathrm{g} / \mathrm{ml}$ gentamicin, and $0.01 \%(\mathrm{w} / \mathrm{v})$ phenol red) media plus amino acids (1.4mM glycine, $0.4 \mathrm{mM}$ alanine, $1 \mathrm{mM}$ glutamine, $2 \%(\mathrm{v} / \mathrm{v})$ essential amino acids, $1 \%(\mathrm{v} / \mathrm{v}$ ) non-essential amino acids; (Gardner et al. 1994) at $39^{\circ} \mathrm{C}$ in humidified atmosphere of $5 \% \mathrm{CO}_{2}$ and $20 \%$ $\mathrm{O}_{2}$ for 7 days. For the without serum treatment group (0\% FBS), $8 \mathrm{mg} / \mathrm{ml}$ of fatty acid free BSA (Sigma) was added to the mSOF media. Culture media for the serum treatment groups (2.5\% FBS) were supplemented with $2.5 \%$ of FBS and $6 \mathrm{mg} / \mathrm{mL}$ fatty acid free BSA. Embryos at the 2-cell embryos were collected prior to culture, while 4-cell, 8-cell, 16-cell, morula and blastocyst stages were collected from each group (0\% FBS and 2.5\% FBS). All stages were collected within the same culture. Embryo collections were replicated 4 times. Embryos were then further processed for immunocytochemical analysis, as described below

All treatment protocols involving the use of animals were approved by the "Comissão de Ética no Uso de Animais" of the Universidade Estadual Paulista in accordance with regulations of the "Conselho Nacional de Controle de Experimentação Animal (CONCEA)". For in vivo (AI) embryos, 8 cows were subjected to the following superovulation protocol: on day 0 , aspiration of dominant follicle (if present) and insertion of a progesterone implant for 7 days (Crestar; Intervet, Brazil); on days 4-7 i.m. injections of Follitropin-V (Bioniche Animal Health Canada, Belleville, Canada) every $12 \mathrm{~h}$, in daily decreasing doses (total dose of $200 \mathrm{mg}$ ); on day 6, 500 $\mu$ g cloprostenol (Sincrocio; Ouro Fino, Brazil); on day 8, 1ug Buserelin Acetate (Sincrofort; Ouro Fino); and insemination at 12 and $24 \mathrm{~h}$ post-Buserelin injection (day 9).

At 5.5 days post AI, morula stage embryos were collected by non-surgical flushing of the uterus with sterile phosphate buffered saline (PBS). Embryos were then further processed for immunocytochemical analysis.
Immunocytochemical analysis of histone H3R26 di-methylation

The zona pellucida was removed from each embryo by incubating in $0.1 \%$ Tyrode's solution (Sigma) for 30 seconds at $37^{\circ} \mathrm{C}$, then $0.5 \%(\mathrm{w} / \mathrm{v})$ pronase at $37^{\circ} \mathrm{c}$ for 10 seconds. Embryos were then quickly placed in $4 \%(\mathrm{w} / \mathrm{v})$ paraformaldehyde for 15 to 20 minutes at room temp and stored in PBS with $0.1 \%$ Triton-X at $4 \mathrm{C}$, until further processed.

Immunofluorescence analysis was performed as previously described (Arnold et al. 2008). Briefly, after washing in PBS, samples were exposed to blocking buffer [3\% (w/v) bovine serum albumin (BSA; Sigma) and 0.1\% (v/v) Tween-20 (Sigma) in PBS] for 20 minutes at room temperature. Primary antibody for histone H3R26me2 (07-215; EMD Millipore, Billerica, MA) was diluted 1:200 in blocking buffer and mixed with samples overnight at $4^{\circ} \mathrm{C}$. Samples were then washed in PBS and exposed to an Alexa Fluor 555-conjugated secondary antibody [diluted 1:200 in block; (Invitrogen, Eugene, Oregon, USA)]. Embryonic DNA was visualized by Hoechst $33342(10 \mu \mathrm{g} / \mathrm{mL}$; Invitrogen). Fluorescence was visualized and images captured using an epifluorescence microscope (Olympus/ IX/FLA/70, Tokyo, Japan) with a CCD camera. To measure protein abundance during early development, embryos of different stages (2-cell, 4-cell, 8-cell, 16-cell, morula and blastocyst; $n=25$-28 embryos per stage) and treatments (with and without serum) were processed at the same time and mounted on the same microscope slide. In vivo morula embryos were processed with morula stage embryos from both in vitro groups (0\% FBS and 2.5\% FBS; $n=15-$ 20 per group). Image-capture parameters below saturation were identified for each slide and images for both H3R26me2 and DNA for each embryo were recorded under identical conditions. Fluorescence was quantified using Image $1.36 \mathrm{~b}$ software (National Institutes of Health, Bethesda, MD). For each embryo, the staining intensity for H3R26me2 was normalized to the DNA, enabling means and standard errors of the means to be calculated.

\section{Statistical analysis}

The experimental data were analyzed using the ANOVA model of SAS. Dependent and independent variables were established according to the experimental design. Duncan's multiple range test was used to assess differences between stages of development, presence or absence of serum during culture and in vivo versus in vitro embryos.

\section{RESULTS}

\section{Effect of serum on embryo development}

The presence of $2.5 \%$ FBS had no effect on cleavage rates, when compared to the 0\% FBS group (Table 1). However, development to the blastocyst stage was increased when FBS was present in the culture media $(\mathrm{P}<0.05)$. In addition, embryos cultured in the absence of FBS tended to be delayed in their development, with most reaching the blastocyst stage by day 8 , as opposed to day 7 for the serum group.

Table 1. Cleavage and development rates of bovine embryos produced in vitro with different concentrations of FBS $(0 \%$ or $2.5 \%)$

\begin{tabular}{lcccc}
\hline Treatment & $\mathrm{n}$ & $\begin{array}{c}\text { Cleavage } \\
(\%)\end{array}$ & $\begin{array}{c}\text { Blastocysts } \\
\text { (\% total) }\end{array}$ & $\begin{array}{c}\text { Blastocsyts } \\
\text { (\% cleavage) }\end{array}$ \\
\hline $0 \%$ FBS & 993 & $80.35 \pm 2.61$ & $18.83 \pm 2.79^{\mathrm{a}}$ & $23.38 \pm 2.93^{\mathrm{a}}$ \\
$2.5 \%$ FBS & 999 & $83.58 \pm 2.55$ & $29.13 \pm 4.77^{\mathrm{b}}$ & $34.85 \pm 5.43^{\mathrm{b}}$
\end{tabular}

$\overline{a, b}$ Values with different superscripts differ between lines $(p<0.05)$. The percentages of cleaved embryos were calculated in relation to the total number of oocytes. The percentages of blastocysts were calculated by the total number of oocytes (\%) and number of embryos cleaved (\% cleaved). 


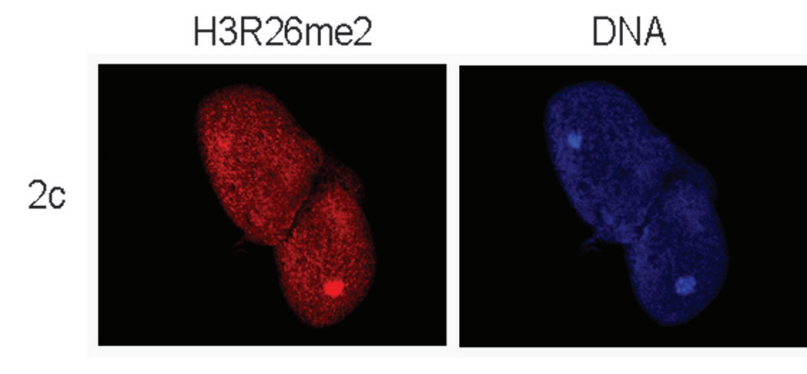

Fig.1. Immunofluorescence for H3R26me2 across early development in in vitro produced bovine embryos. Immunofluorescence for H3R26me2 (red) in 2 cells (2c), 4 cells (4c), 8 cells (8c), 16 (16) cells, morula (mol) and blastocysts (bl) grown with $0 \%$ and with $2.5 \%$ fetal bovine serum. Total DNA is shown in blue.

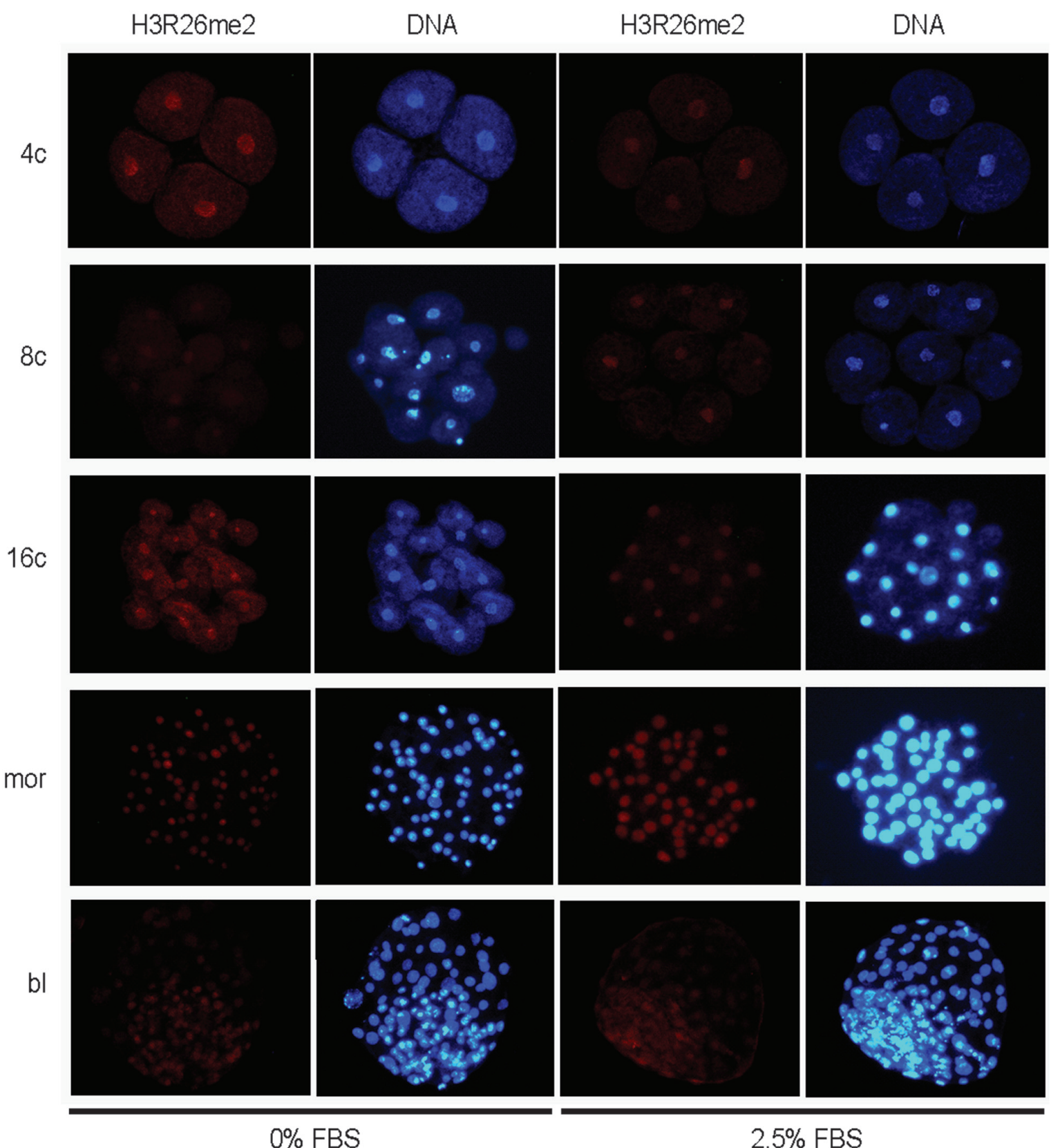

Immunofluorescene of H3R26me2 during in vitro development

A specific antibody to H3R26me2 was utilized to evaluate fluctuations during in vitro development of IVP embryos cultured with and without fetal bovine serum (Fig.1). Overall levels of H3R26me2 changed across development
(Fig.2). Both treatment groups had elevated levels at the 4-cell stage, with the 2.5\% FBS group significantly higher $(\mathrm{P}<0.05)$ than the $0 \%$ group (Fig.2). The $0 \%$ FBS groups had higher levels at the 16-cell and morula stages, when compared to similar stage embryos cultured with $2.5 \%$ FBS (Fig.2). Comparing within the 0\% FBS treatment, the 16- 


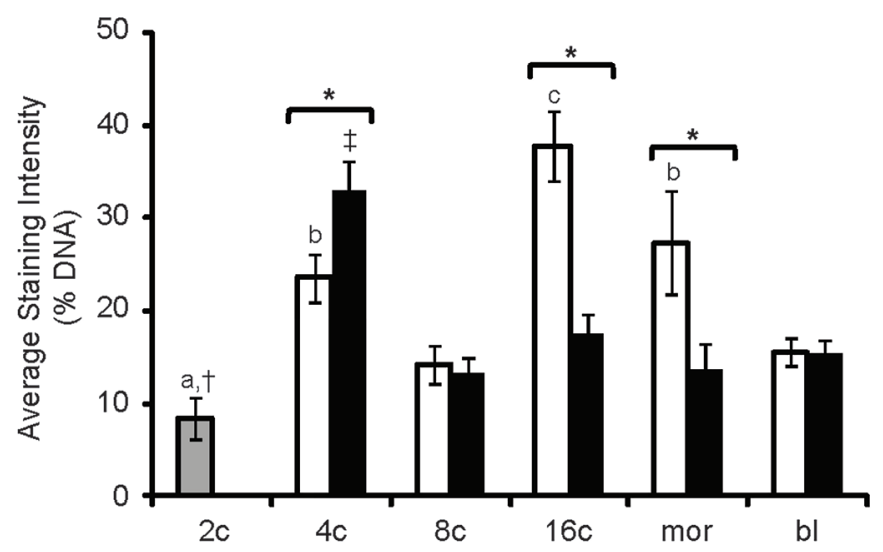

Fig.2. Average intensity of H3R26me2 at different stages of embryonic development in response to supplementation of $0 \%$ and $2.5 \%$ fetal bovine serum (FBS) to culture media. ${ }^{*}$ Differences in levels between 0\% (white) and 2.5\% (black) FBS. a,b,c Differences between embryo stages grown in media supplemented with 0\% FBS. ${ }^{\dagger, \neq}$ Differences between embryo stages grown in media supplemented with 2.5\% FBS. 2-cell embryos were collected prior to culture and set to 1 for comparisons between embryo stages. Results presented as percentage of total DNA $\left({ }^{*}, \mathrm{a}, \mathrm{b}, \mathrm{c},+, \neq \mathrm{P}<0.05\right)$.

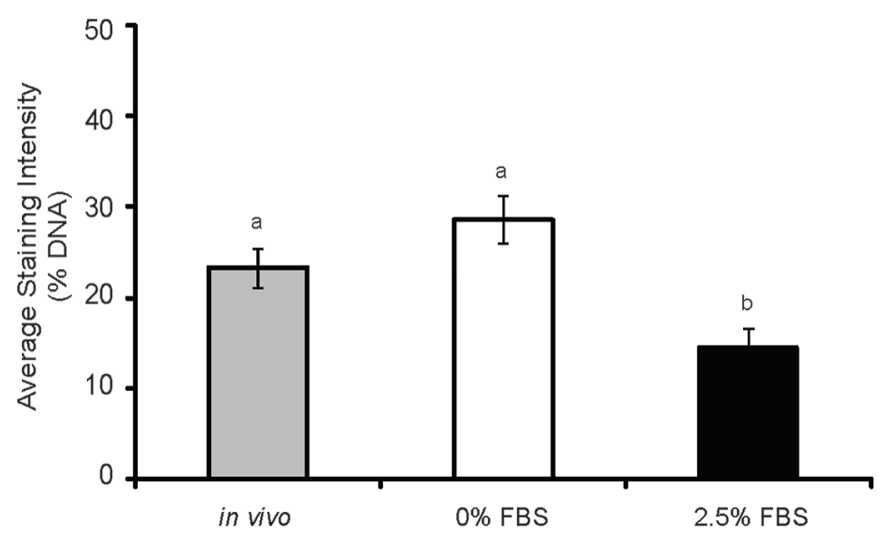

Fig.3. Average intensity for H3R26me2 for morula stage embryos produced in vitro or in vitro culture supplemented with $0 \%$ or $2.5 \%$ fetal bovine serum. Results presented as percentage of total DNA $\left.{ }^{*}, \mathrm{a}, \mathrm{b}, \mathrm{c}, \mathrm{P}<0.05\right)$.

cell stage had the highest levels of H3R26me2, followed by 4-cell and morula stage embryos (Fig.2). For the 2.5\% FBS group, only the 4-cell stage embryos had significantly more H3R26me2 than all other stages (Fig.2).

\section{Immunofluorescene of H3R26me2 for in vivo and in vi- tro morula stage embryos}

To determine which culture condition is more representative of natural embryo development, morula stage embryos were collected from superovulated animals. In vivo morula stage embryos had similar levels of H3R26me2 as the in vitro, 0\% FBS morula embryos (Fig.3). Protein levels of H3R26me2 for both in vivo and 0\% FBS morula embryos were higher than morulas cultured with 2.5\% FBS (Fig.3).

\section{DISCUSSION}

The current study demonstrates that the histone modification H3R26me2 is present and fluctuates depending on the stage of development of bovine embryos. In addition, fetal bovine serum had an effect both on developmental rates and H3R26me2 mark at different stages of development. The presence of $2.5 \%$ FBS increased development rates to the blastocyst stage and a higher level of H3R26me 2 at the 4 -cell stage. When embryos were cultured without FBS, an increase was witnessed at the 4-cell stage, as well as in 16cell and morula stage embryos. Interestingly, in vivo morula stage embryos were more similar to the $0 \%$ FBS group in regards to H3R26me2 levels, both being higher than embryos cultured with $2.5 \%$ FBS.

The use of fetal bovine serum in culture media has been controversial with both positive and negative effects reported. Several studies have demonstrated increased blastocyst development when FBS is supplemented, (Lazzari et al. 2002, Rizos et al. 2003, Leivas et al. 2011) similar to the current study. However, the use of FBS has also been associated with abnormal fetal growth, in subsequent pregnancies (Young et al. 1998, Lazzari et al. 2002, Farin et al. 2004). However, these latter studies supplemented FBS up to $10 \%$, while the current study utilized $2.5 \%$. In addition, FBS has an adverse effect on embryo survival after cryopreservation, due to increased lipid content within the embryos (Rizos et al. 2003). Leivas and co-authors (Leivas et al. 2011) also suggest that embryos from certain breeds of cattle may depend more on the presence of FBS in the culture media. Similar to the current study, they report a $10 \%$ increase in blastocyst rates between IVP embryos from Bos indicus cattle cultured with 2\% FBS than embryos cultured with BSA alone (Leivas et al. 2011). For this reason, many laboratories in South America, where most cattle are of Bos indicus origin, still utilize FBS during embryo culture.

While most research in serum supplementation during in vitro culture have focused on developmental rates and gene expression [for review see (Lonergan et al. 2003), few studies have evaluated the effects on epigenetic processes, such as histone modifications. Research on histone modifications in embryos primarily investigates the asymmetric distribution between male and female pronuclei [(Mason et al. 2012). Studies addressing the issue of specific histone modifications are starting to demonstrate how dynamic and vital these epigenetic marks are during development. Ross and co-authors (Ross et al. 2008) reported, in a bovine model, that tri-methylation of H3K27 is highest in GV ooocytes, declines in mature oocytes and across embryo development to the morula stage, then increases in blastocyst embryos. In addition, the enzymes that methylate H3K27 follow a similar pattern (Ross et al. 2008). In human embryos, H3K27me3 is relatively static to the 8-cell stage, where it declines, increasing again at the blastocyst stage (Zhang et al. 2012). In mice blastocysts, H3K27me3 is asymmetrically distributed between the ICM and trophoblast cells, as well as being enriched on the inactive $\mathrm{X}$ chromosome in the trophectoderm (Erhardt et al. 2003, Dahl et al. 2010). Human embryos also have dynamic changes in the permissive histone mark, H3K4me3 during development to the blastocyst stage (Zhang et al. 2012). These authors observed an increase in H3K4me3 from the pronuclear stage to the 4-cell stage, followed by a decline at 
the 8-cell stage and another increase to the blastocyst stage (Zhang et al. 2012). These authors suggest the changes observed for both H3K4me3 and H3K27me3 from the 4-cell to 8-cell stage may be associated with embryonic genome activation, (Zhang et al. 2012) which occurs during this time in human embryos (Dobson et al. 2004).

The current study evaluated the histone mark H3R$26 \mathrm{me} 2$, which has not been reported in a bovine model. Di-methylation of H3R26 has been associated with gene expression (Di Lorenzo \& Bedford 2011). Due to this residue's physical proximity on histone $\mathrm{H} 3$ to amino acid residue K27, which when methylated is a major repressive mark, methylation of H3R26 may inhibit the Polycomb repressive complex from methylating H3K27 (Di Lorenzo \& Bedford 2011). In addition, H3R26me2 is critical for embryo development in a mouse model. According to Torres-Padilla et al. (2007), the levels of methylation of arginine residues in histone H3-specific (H3R26me2, R2me and R17me) are present in mouse embryos and may play a role in subsequent cellular differentiation. They reported different levels of H3R26me2 between blastomeres of the 4-cell stage embryos. The blastomeres with the least amount of H3R26me2 would give rise to the trophectoderm (Torres-Padilla et al. 2007). In addition, overexpression of the histone methyltransferase that methylates H3R26, PRMT4/CARM1, in blastomeres resulted in subsequent development into the inner cell mass (Torres-Padilla et al. 2007). In the current study, differences between blastomeres were not evaluated. Our main objective was to determine the profile of H3R26me2 in bovine embryos, in response to serum supplementation during culture. Future studies are planned to assess differences in H3R26me2 concentrations between blastomeres, as well as the expression/activation of PRMT4/CARM1. However, in the current study, there appears to be a difference in H3R$26 \mathrm{me} 2$ staining intensities between the inner cell mass and the trophectoderm of the blastocyst.

Concentrations of H3R $26 \mathrm{me} 2$ were significantly increased at the 4-cell stage, regardless of serum. This result may suggest a possible role in priming the DNA for embryonic genome activation. Embryonic genome activation (EGA) is the moment where the embryo begins to produce its own factors (Telford et al. 1990). Up until EGA, embryonic development utilizes the maternal mRNA and proteins that were stored in the mature oocyte. In cattle, EGA occurs in the stage of 8-16 cells (Kopecný et al. 1989). However, Kanka and co-authors (Kanka et al. 2009) have demonstrated transcriptional activity of a few genes in 4-cell stage bovine embryos. This increase in transcription of selected genes, prior to the global activation at the 8 to 16 -cell stage has been referred to as the "minor genome activation" and has been reported in several species [for review see (Tadros \& Lipshitz 2009). Further studies are needed to determine if the increase in H3R26me2 levels observed in the 4-cell embryos in the present study are associated with minor activation of the embryonic genome. The increase in H3R26me2 at the 4-cell stage was observed in both groups, with the $2.5 \%$ FBS group containing a higher concentration. How these results represent in vivo conditions is of interest. However, the difficulty of collecting 4-cell stage in vivo produced embryos inhibited this experiment from being performed at this time

In the serum-free group, an increase in H3R26me2 was also seen at the 16-cell and morula stage. This stage of embryos also coincides with the first cellular differentiation into cells of the inner cell mass and trophectoderm (McLaren 1990). These results may suggest a similar role for this epigenetic mark as seen in the 4-cell mouse model (Torres-Padilla et al. 2007). However, in the $2.5 \%$ FBS group, no such increase was observed. These results suggest that either the embryos cultured in the absence of FBS require alterations in this histone modification (and in turn gene expression, in order to compensate for the lack of essential factors present in the serum), or factors within FBS inhibit the normal increase in H3R26me2 during this time. To address this issue in vivo produced morula stage embryos were collected and evaluated. Levels of H3R26me2 in morula stage embryos produced in vivo were similar to those observed in the $0 \%$ FBS group and higher than those in embryo supplemented with $2.5 \%$ FBS. These results suggest that the increase in H3R26me2 observed in the $0 \% \mathrm{FBS}$, is more similar to the profile of naturally in vivo developing embryos, and the presence of FBS inhibits this increase in H3R26me2. Future studies are required to determine which genes are associated with H3R26me2, and if the presence of serum altered expression of these genes.

\section{CONCLUSIONS}

The histone modification H3R26me2 is present during the embryonic preimplantation period in cattle, and its level varies during development.

These variations between embryo stages coincide with important development milestones of embryo development; embryonic genome activation and first cellular differentiation.

Even though supplementation of fetal bovine serum, during in vitro culture, increased developmental rates to the blastocyst stage, the H3R26me2 profile was altered when compared to embryos cultured in serum-free media or produced in vivo.

These results suggest that when the embryo begins to produce its own factors, in the stage of 8-16 cells, unknown factors in fetal bovine serum affect this epigenetic mark, which may lead to altered transcriptional regulation that could lead to a change in the development and subsequent embryo loss.

This research provides evidence that media components and additives can influence epigenetic processes, and such effects should be carefully investigated.

Future studies are needed to determine how these variations on modification of histones, like H3R26me2, can affect embryonic development, and how to handle these variations to improve the in vitro production of embryos.

Acknowledgements.- The authors would like to thank Carlos V. da Rocha, Roberta Vantini, Natalia Rocha, Beatriz Leão and Priscila Dall Acqua for invaluable technical assistance during the production embryos. Funding for this project was supported by the Fundação de Apoio a Pesquisa do Estado de São Paulo, Brazil (FAPESP, grant 2009/50381-5 to F.L. Lopes). D.R. Arnold, C.A.P. Corrêa, L.L.G. Lorena, R.C. Gaspar, and F.L. Lopes had 
scholarships funded by FAPESP. J.C.T. Penteado holds a scholarship from the Coordenação de Aperfeiçoamento de Pessoal de Nível Superior, Brazil (CAPES).

\section{Authors contribution:}

D.R. Arnold: design, aspiration, IVC, immunofluorescence, embryo selection in vitro and in vivo, statistics, figures, writing;

C.A.P. Corrêa: aspiration, maturation, IVF, IVC, immunofluorescence;

L.L.G. Lorena: IVC, immunofluorescence, embryo selection in vivo, figures, writing;

R.C. Gaspar: aspiration, maturation, IVF, IVC, embryo selection in vitro;

G.F. Rossi: aspiration, evaluation of cows, hormonal treatment of cows, artificial insemination, embryo flushing;

A.M. Ifran: evaluation of cows, hormonal treatment of cows, artificial insemination, embryo flushing;

J.C.T. Penteado: aspiration, evaluation of cows, hormonal treatment of cows, embryo flushing;

G. Mingoti: design, IVC, writing;

F.L. Lopes: design, aspiration, embryo selection in vitro, statistics, writing.

\section{REFERENCES}

Arnold D.R., Françon P., Zhang J., Martin K. \& Clarke H.J. 2008. Stem-loop binding protein expressed in growing oocytes is required for accumulation of mRNAs encoding histones $\mathrm{H} 3$ and $\mathrm{H} 4$ and for early embryonic development in the mouse. Dev. Biol. 313:347-358.

Besenfelder U., Havlicek V. \& Brem G. 2012. Role of the oviduct in early embryo development. Reprod. Domest. Anim. 47(Suppl.4):156-163.

Bordignon V., Keyston R., Lazaris A., Bilodeau A.S., Pontes J.H., Arnold D., Fecteau G., Keefer C. \& Smith L.C. 2003. Transgene expression of green fluorescent protein and germ line transmission in cloned calves derived from in vitro-transfected somatic cells. Biol. Reprod. 68:2013-2023.

Corry G.N., Tanasijevic B., Barry E.R., Krueger W. \& Rasmussen T.P. 2009. Epigenetic regulatory mechanisms during preimplantation development. Birth Defects Res. C, Embryo Today 87:297-313.

Dahl J.A., Reiner A.H., Klungland A., Wakayama T. \& Collas P. 2010. Histone H3 lysine 27 methylation asymmetry on developmentally-regulated promoters distinguish the first two lineages in mouse preimplantation embryos. PLoS One 5:e9150.

Di Lorenzo A. \& Bedford M.T. 2011. Histone arginine methylation. FEBS Lett. 585:2024-2031.

Dobson A.T., Raja R., Abeyta M.J., Taylor T., Shen S., Haqq C. \& Pera R.A. 2004. The unique transcriptome through day 3 of human preimplantation development. Hum. Mol. Genet. 13:1461-1470.

Duranthon V., Watson A.J. \& Lonergan P. 2008. Preimplantation embryo programming: transcription, epigenetics, and culture environment. Reproduction 135:141-150.

Enright B.P., Sung L.Y., Chang C.C., Yang X. \& Tian X.C. 2005. Methylation and acetylation characteristics of cloned bovine embryos from donor cells treated with 5-aza-2'-deoxycytidine. Biol. Reprod. 72:944-948.

Erhardt S., Su I.H., Schneider R., Barton S., Bannister A.J., Perez-Burgos L., Jenuwein T., Kouzarides T., Tarakhovsky A. \& Surani M.A. 2003. Consequences of the depletion of zygotic and embryonic enhancer of zeste 2 during preimplantation mouse development. Development 130:42354248.

Farin C.E., Farin P.W. \& Piedrahita J.A. 2004. Development of fetuses from in vitro-produced and cloned bovine embryos. J. Anim. Sci. 82(Suppl.):E53-62.

Gao Y., Hyttel P. \& Hall V.J. 2010. Regulation of H3K27me3 and H3K4me3 during early porcine embryonic development. Mol. Reprod. Dev. 77:540549.

Gardner D.K. 1998. Changes in requirements and utilization of nutrients during mammalian preimplantation embryo development and their significance in embryo culture. Theriogenology 49:83-102.

Gardner D.K., Lane M., Spitzer A. \& Batt P.A. 1994. Enhanced rates of cleavage and development for sheep zygotes cultured to the blastocyst stage in vitro in the absence of serum and somatic cells: amino acids, vitamins, and culturing embryos in groups stimulate development. Biol. Reprod. 50:390-400.

Hansen P.J., Block J., Loureiro B., Bonilla L. \& Hendricks K.E. 2010. Effects of gamete source and culture conditions on the competence of in vitro-produced embryos for post-transfer survival in cattle. Reprod. Fertil. Dev. 22:59-66.

Hou J., Liu L., Zhang J., Cui X.H., Yan F.X., Guan H., Chen Y.F. \& An X.R. 2008. Epigenetic modification of histone 3 at lysine 9 in sheep zygotes and its relationship with DNA methylation. BMC Dev. Biol. 8:60.

Kanka J., Kepková K. \& Nemcová L. 2009. Gene expression during minor genome activation in preimplantation bovine development. Theriogenology 72:572-583.

Khosla S., Dean W., Reik W. \& Feil R. 2001. Culture of preimplantation embryos and its long-term effects on gene expression and phenotype. Hum. Reprod. Update 7:419-427.

Kohda T., Kishigami S., Kaneko-Ishino T., Wakayama T. \& Ishino F. 2012. Gene expression profile normalization in cloned mice by trichostatin A treatment. Cell Reprogram. 14:45-55.

Kopecný V., Fléchon J.E., Camous S. \& Fulka J. 1989. Nucleologenesis and the onset of transcription in the eight-cell bovine embryo: fine-structural autoradiographic study. Mol. Reprod. Dev. 1:79-90.

Lazzari G., Wrenzycki C., Herrmann D., Duchi R., Kruip T., Niemann H. \& Galli C. 2002. Cellular and molecular deviations in bovine in vitro-produced embryos are related to the large offspring syndrome. Biol. Reprod. 67:767-775.

Leivas F.G., Brum D.S., Fialho S.S., Saliba W.P., Alvim M.T., Bernardi M.L., Rubin M.I. \& Silva C.A. 2011. Fetal calf serum enhances in vitro production of Bos taurus indicus embryos. Theriogenology 75:429-433.

Lonergan P., Fair T., Corcoran D. \& Evans A.C. 2006. Effect of culture environment on gene expression and developmental characteristics in IVFderived embryos. Theriogenology 65:137-152.

Lonergan P., Rizos D., Gutierrez-Adán A., Moreira P.M., Pintado B., de la Fuente J. \& Boland M.P. 2003. Temporal divergence in the pattern of messenger RNA expression in bovine embryos cultured from the zygote to blastocyst stage in vitro or in vivo. Biol. Reprod. 69:1424-1431.

Maalouf W.E., Alberio R. \& Campbell K.H. 2008. Differential acetylation of histone $\mathrm{H} 4$ lysine during development of in vitro fertilized, cloned and parthenogenetically activated bovine embryos. Epigenetics 3:199-209.

Mason K., Liu Z., Aguirre-Lavin T. \& Beaujean N. 2012. Chromatin and epigenetic modifications during early mammalian development. Anim. Reprod. Sci. 134:45-55.

McLaren A. 1990. The Embryo. Cambridge University Press, Cambridge, UK. Morgan H.D., Santos F., Green K., Dean W. \& Reik W. 2005. Epigenetic reprogramming in mammals. Hum. Mol. Genet. 14(Spec. No.1):R47-58.

Niemann H. \& Wrenzycki C. 2000. Alterations of expression of developmentally important genes in preimplantation bovine embryos by in vitro culture conditions: implications for subsequent development. Theriogenology 53:21-34.

Palini S., De Stefani S., Scala V., Dusi L. \& Bulletti C. 2011. Epigenetic regulatory mechanisms during preimplantation embryo development. Ann. N.Y. Acad. Sci. 1221:54-60.

Park K.E., Magnani L. \& Cabot R.A. 2009. Differential remodeling of monoand trimethylated H3K27 during porcine embryo development. Mol. Reprod. Dev. 76:1033-1042.

Parrish J.J., Susko-Parrish J.L., Leibfried-Rutledge M.L., Critser E.S., Eyestone W.H. \& First N.L. 1986. Bovine in vitro fertilization with frozenthawed semen. Theriogenology 25:591-600.

Rizos D., Gutiérrez-Adán A., Pérez-Garnelo S., De La Fuente J., Boland M.P. \& Lonergan P. 2003. Bovine embryo culture in the presence or absence of serum: implications for blastocyst development, cryotolerance, and messenger RNA expression. Biol. Reprod. 68:236-243.

Ross P.J., Ragina N.P., Rodriguez R.M., Iager A.E., Siripattarapravat K., Lopez-Corrales N. \& Cibelli J.B. 2008. Polycomb gene expression and histone $\mathrm{H} 3$ lysine 27 trimethylation changes during bovine preimplantation development. Reproduction 136:777-785. 
Santos F., Zakhartchenko V., Stojkovic M., Peters A., Jenuwein T., Wolf E., Reik W. \& Dean W. 2003. Epigenetic marking correlates with developmental potential in cloned bovine preimplantation embryos. Curr. Biol. 13:1116-1121.

Sarmento O.F., Digilio L.C., Wang Y., Perlin J., Herr J.C., Allis C.D. \& Coonrod S.A. 2004. Dynamic alterations of specific histone modifications during early murine development. J. Cell Sci. 117:4449-4459.

Steptoe P.C. \& Edwards R.G. 1978. Birth after the reimplantation of a human embryo. Lancet 2:366.

Stroud B. 2012. The year 2011 worldwide statistics of embryo transfer of domestic farm animals. IETS Newsletter 50:16-25.

Tadros W. \& Lipshitz H.D. 2009. The maternal-to-zygotic transition: a play in two acts. Development 136:3033-3042.

Telford N.A., Watson A.J. \& Schultz G.A. 1990. Transition from maternal to embryonic control in early mammalian development: a comparison of several species. Mol. Reprod. Dev. 26:90-100.

Thompson J.G. 2000. In vitro culture and embryo metabolism of cattle and sheep embryos - a decade of achievement. Anim. Reprod. Sci. 60-61: 263-275.

Torres-Padilla M.E., Parfitt D.E., Kouzarides T. \& Zernicka-Goetz M. 2007. Histone arginine methylation regulates pluripotency in the early mouse embryo. Nature 445:214-218.

Van Langendonckt A., Donnay I., Schuurbiers N., Auquier P., Carolan C., Massip A. \& Dessy F. 1997. Effects of supplementation with fetal calf serum on development of bovine embryos in synthetic oviduct fluid medium. J. Reprod. Fertil. 109:87-93.

Wee G., Koo D.B., Song B.S., Kim J.S., Kang M.J., Moon S.J., Kang Y.K., Lee K.K., Han YM. 2006. Inheritable histone $\mathrm{H} 4$ acetylation of somatic chromatins in cloned embryos. J. Biol. Chem. 281:6048-6057.

Young L.E., Sinclair K.D. \& Wilmut I. 1998. Large offspring syndrome in cattle and sheep. Rev. Reprod. 3:155-163.

Zhang A., Xu B., Sun Y., Lu X., Gu R., Wu L., Feng Y. \& Xu C. 2012. Dynamic changes of histone $\mathrm{H} 3$ trimethylated at positions K4 and K27 in human oocytes and preimplantation embryos. Fertil. Steril. 98:1009-1016. 